\title{
DOENÇA DE STILL DO ADULTO: UM RELATO DE CASO
}

\author{
Ana Claudia Kurmann ${ }^{1}$, Alessandra Faggion Mocellin², Elisa Frana ${ }^{2}$, Emanuela Lando ${ }^{2}$, Lhaís de Lima Zanotto ${ }^{2}$, Natani \\ Menegolla ${ }^{2}$, Paola Dal Molin Felizola ${ }^{2}$, Thais Rohde Pavan ${ }^{3}$ \\ ${ }^{1}$ Acadêmica de medicina da Universidade de Passo Fundo \\ 2 Acadêmicas de medicina da Faculdade Meridional (IMED) \\ ${ }^{3}$ Médica reumatologista e professora de reumatologia da Universidade de Passo Fundo (UPF) e Instituto Meridional (IMED)
}

\section{INTRODUÇÃO}

Doença de Still do Adulto (DSA) é uma rara enfermidade inflamatória de etiologia desconhecida e acometimento sistêmico variante à artrite idiopática juvenil ${ }^{1}$. Clinicamente manifesta-se como rash cutâneo, febre intermitente, poliartrite e inúmeros acometimentos sistêmicos ${ }^{2}$. Não existem exames laboratoriais, achados histopatológicos ou testes conclusivos na identificação da doença, sendo, majoritariamente, diagnóstico de exclusão ${ }^{3}$. O tratamento é comandado pelo uso de drogas modificadoras de doença (DMARD) e varia de acordo com o quadro clínico individual $^{4}$.

\section{OBJETIVOS}

O presente relato visa discutir o caso de uma paciente que desenvolveu DSA.

\section{RELATO DO CASO}

Paciente feminina, 46 anos, apresenta há 20 dias quadro de astenia, mialgia, artralgia difusa, picos febris vespertinos $\left(39^{\circ} \mathrm{C}\right)$, calafrios, linfonodomegalias cervicais e axilares, lesões cutâneas eritematosas e pruginosas. Possuía leucocitose (32.710, 65\% de neutrófilos), PCR 123, VSG 48, ferritina > 2000, FAN e anti-DNA nativo não reagentes. Desta forma, após exclusão de diagnósticos diferenciais, conclui-se que a paciente possuía DSA. Devido a picos pressóricos, optou-se por não realizar pulsoterapia; a paciente foi tratada recebendo doses equivalentes de prednisona, obtendo melhora significativa dos sintomas e, em seguida, iniciou-se metotrexate e ácido fólico.

\section{DISCUSSÃO}

A base para o diagnóstico da DSA é a exclusão de patologias diferenciais. O uso de prednisona, metotrexate e ácido fólico, são preferíveis, diante de estudos que relatam que a leflunomida está associada à Síndrome de Ativação Macrofágica (SAM). Essa, deve ser sempre investigada em pacientes com quadro agudo de febre persistente, hepatoesplenomegalia, insuficiência hepática aguda e pancitopenia e prontamente tratada em virtude da potencial letalidade. $^{5}$
A hiperferritinemia é encontrada em muitos casos, e pode ser usada como marcador, já que seus níveis excedem os encontrados em outras doenças reumáticas, isso porque, na doença ativa, a síntese rápida de ferritina supera a sua taxa de incorporação do ferro, aumentando assim seus índices. ${ }^{6}$

\section{CONCLUSÃO}

Embora rara, a DSA deve ser sempre considerada em pacientes com envolvimento sistêmico e poliartrite, após exclusão de outras doenças, principalmente doenças infecciosas e neoplásicas. Seu curso é geralmente crônico e a principal sequela observada é o bloqueio de punhos, em razão de anquilose óssea. ${ }^{7}$

\section{REIERENCIAS}

1. CARBAnElas, N. et al. Avanços no Conhecimento da Doença de Still do Adulto. Acta Med Port., v. 24, p. 183-192. 2011.

2. Cush JJ. Adult-onset Still's disease. Bull Rheum Dis 2000;49(6):1-4.

3. Garcia-Porrua C, Gonzalez-Gay MA, Crespo F, Gonzalez-Juanatey C. Adult onset Still's disease in Catalonia, Spain. J Rheumatol 2000;27(1):280-1.

4. Al-Arfaj AS, Al-Saleh S. Adult-Onset Still's disease in Saudi Arabia. Clin Rheumatol 2001;20(3):197-200

5. Schade. L; Fritsch S.; Gentili A.C.; Noronha L.; Azevedo V.F.; Paiva E.S. Síndrome de ativação macrofágica após uso de Leflunomida em paciente com doença de Still do adulto: relato de caso. Rev. Bras. Reumatol. vol.53 no.6 São Paulo Nov./Dec. 2013

6. Freire M.; Teodoro R.B.; Oliveira L.B.; Camargo Y. M.S.; Doença de Still do Adulto - um desafio diagnóstico na febre de origem indeterminada. Rev. Bras. Reumatol. vol.45 no.5 São Paulo Sept./Oct. 2005

7. Appenzeller S.; Castro W. G.; Costallat L. T. L.; Samara M. A.; Bértolo B. M. Doença de still do adulto: diagnóstico e evolução. Revista Brasileira Reumatologia, v. 43, n. 6, p. 352-7. 2003 